process had been worked out in Sweden, a method still used and of great importance in Scandinavia. Hägglund had already, in 1911, been investigating this problem at the University of Stockholm, collaborating with the inventors of this process. $\mathrm{He}$ was thus predestined for an industrial position. The step from the university to industry was then very unusual, in Sweden at least. However, Hägglund found his right field of work and contributed sub. stantially to the ultimate success of the 'sulphitealcohol' venture. The first and, even by now, the only scientific account of this interesting fermentation is given in his monograph, "Die Sulfitablauge und ihre Verarbeitung auf Alkohol" (1921).

It was quite logical for a man of Hägglund's acumen to inquire further into the problem of converting wood into alcohol--the hydrolysis of the main constituent of wood, the cellulose--to produce fermentable sugars. This difficult problem had already received a great deal of attention in many quarters, but in vain. The only technique of practical use existing is that developed by Hägglund and Bergius, the so-called Rheinau-method (1917) in which hydrochloric acid is used as hydrolysing agent.

The great ability of this young scientist in solving intricate technical problems by application of fundamentals was early recognized in academic circles. In 1920, Hägglund accepted the chair of the chemistry of wood products especially established for him at Albo Akademi, the Swedish-language university of the new Republic of Finland. A flourishing school of cellulose research came into being, the research output became formidable and many of the fundamentals of the speciality established. Hägglund's work formed a continuation of that of the grand old man of lignin chemistry, Peter Klason, emeritus professor of chemical technology in the Royal Institute of Technology in Stockholm. Actually, Hägglund became the spiritual successor to Klason in 1930 , when a chair in wood chemistry and technology was founded at the Royal Institute, through donations from the pulp and paper industries. Fourteen years later, the Swedish Government erected an institute for pulp and paper research, probably the largest and best equipped institute of its kind at that time, constituting $a$ unit of the Royal Institute.

Hägglund and his many pupils - of whom quite a number occupy leading positions in this key-industry of Sweden at the present time-have, during the past twenty-five years, investigated practically every phase of the wood-pulping processes and paper making. Work of a fundamental theoretical nature as well as important contributions to technological aspects of this industry, which is, of course, of great importance for Sweden, have emanated from the Hägglund school. Among his numerous co-workers, Adler, Enkvist, Erdtman, Giertz and Johnson were prominent. It is generally conceded that Hägglund did more than any other single individual to unravel the intricacies of the 'cooking' processes-his research on the formation of lignosulphonic acids being particularly outstanding. His comprehensive text-books, "Holzchemie" (1928, 1939), "Natronzellstoff" (1926) and "The Chemistry of Wood" (1951), are standard works throughout the world.

His unflagging endeavour in furthering the progress and well-being of the industry to which Hägglund devoted his life gave him an international standing. He was a member of many learned societies at home and abroad and received several honorary degrees, that from the University of Heidelberg giving him great pleasure. Among numerous awards he received was the rare distinction of the Grand Gold Medal of the Royal Swedish Academy of Technical Sciences, and the greatest honour to be given a cellulose chemist, the Ekman and Mitscherlich Gold Medals.

Hägglund was a sterling character, an inspiring colleague and a staunch friend. He will be greatly missed by a large circle of friends and colleagues in many lands.

K. H. Gustavson

\section{Prof. Alfred Kohn}

ATFRED KoHN, professor and director of the Department of Histology of the German University in Prague until 1937, died in Prague on January 15, five weeks before his ninety-second birthday. Born in Libin, Bohemia, he received his medical education at the German University in Prague and, while still a student, became assistant to the histologist, Siegmund Mayer, whom he later succeeded in the chair. For various periods in his career he was a senator of the University and dean of its medical faculty.

Kohn is famous for his work on the parathyroids, which he termed Epithelkörperchen. His contribution was to point out clearly their independence of the thyroid. He was, at least, a silent partner in Gudernatsch's discovery, made in Kohn's institute, that feeding thyroid to tadpoles inhibits their growth but accelerates metamorphosis. His best-known work deals with the paraganglia and the chromaffin system, which terms he introduced. There has been much dispute about the nature of paraganglionic cells, but recent electron microscopical investigations bear out his views. Kohn considered chromaffin cells to be a special category, comparable with epithelium, nerve cells, muscle cells and so forth. They form a link between nervous and endocrine systems. Kohn also made significant contributions to our knowledge of the differentiation of the peripheral nervous system, stressing the early differentiation of nerve cells ("primogenitur", Hauptzellen) and the later differentiation of Schwann cells, paraganglia and suprarenal medulla ("secundogenitur", Nebenzellen).

I worked with him for ten years, and in my view Kohn should be considered a great clarifier who put into focus many structures and problems then only vaguely known or misinterpreted.

During the Nazi occupation of Prague, it seems that some informal protection was first extended to him, but when a Diener of the German Anatomy Department saw Prof. Grosser, the well-known embryologist, talk to the Jew, Kohn, in the street, the seventy-four year old Kohn was deported to a concentration camp. He returned to Prague in 1945 , but he met new difficulties : on account of his German education and his position in the abolished German University, he was deprived of his superannuation; however, following protest in the Czech Press, it was restored. Later, the Communist government bestowed on this entirely unpolitical scientist the Order of Labour, which carries a supplemental income, thus making comfortable the last years of his life. Max Watzka, who succeeded him in Prague and is now editor of the Anatomische Anzeiger and professor of histology in Mainz, is, of all Kohn's disciples, the one who continues most consistently the work of Alfred Kohn.

Rudolf Altschul 